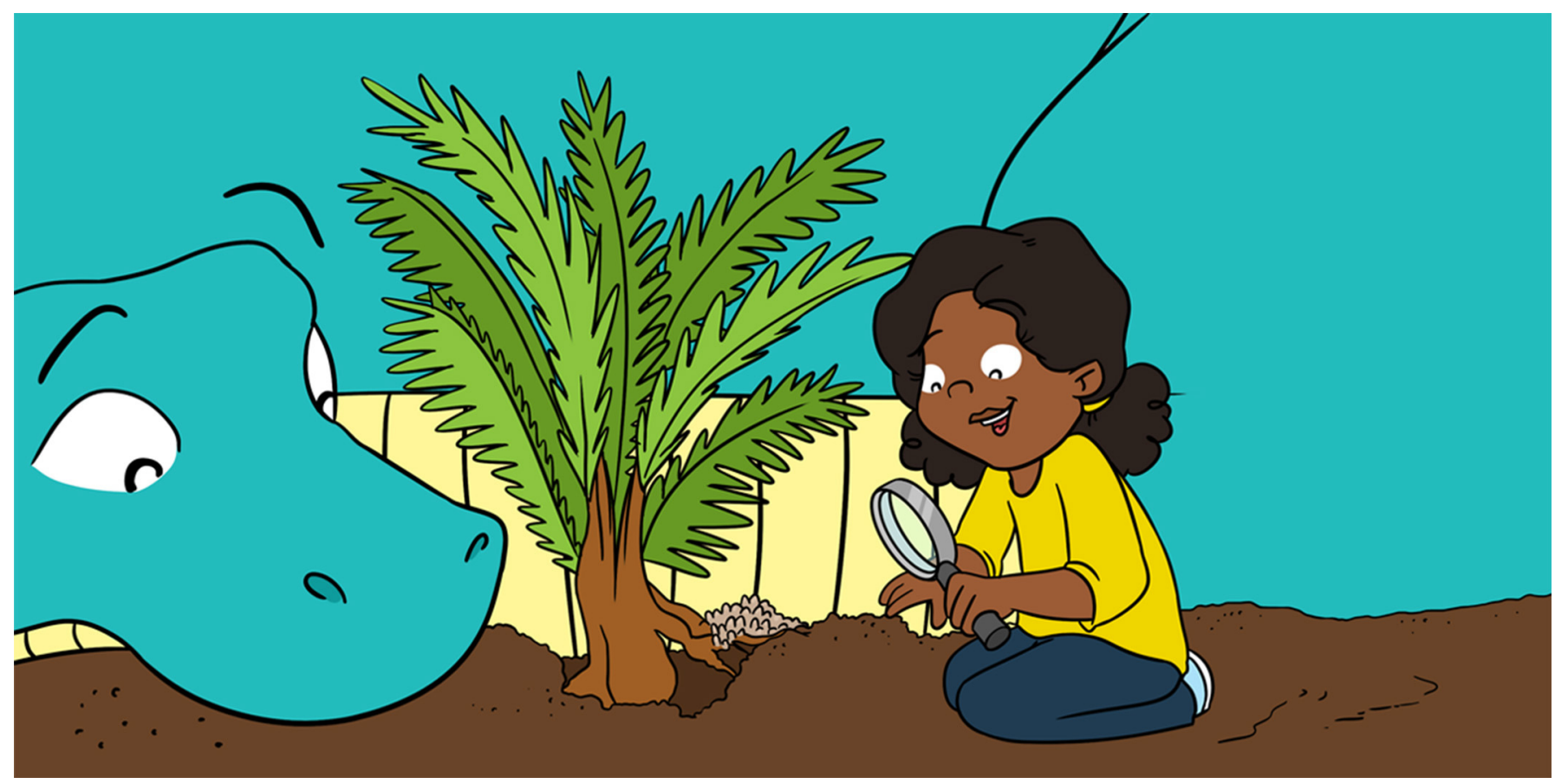

\title{
CYCADS: ANCIENT PLANTS WITH BACTERIA LIVING IN THEIR ROOTS
}

\section{Fernando López Restrepo *, Diego Garfias Gallegos and Pablo de Jesús Suarez Moo}

National Laboratory of Genomics for Biodiversity, Center for Research and Advanced Studies of the National Polytechnic Institute, Irapuato, Mexico

YOUNG REVIEWERS:

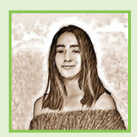

\section{AURA}

AGE: 14

MANU

AGE: 14
Have you ever seen a picture of a dinosaur and realized that there is a palm-like plant by its side? Maybe you have walked around your neighborhood and seen the same kind of plant there? Incredibly, those ancient plants, called cycads, have been around for millions of years. A single cycad plant can live up to 2,000 years! We think that the secret to cycads' survival and long life lies inside a very special structure called the coralloid root, which has microbes living inside it. We studied these coralloid roots and found a high diversity of bacterial species living inside of them, more than anyone had ever imagined. When we took a closer look at these bacteria, we found that they can produce many compounds that can help them communicate among themselves and with the plant, transport nutrients, and perform other functions that are still a mystery.

\section{CYCADS: PLANTS THAT ARE OLDER THAN THE DINOSAURS}

Cycads are ancient seed-bearing plants that appeared before the age of dinosaurs, during the Permian period, almost 280 million years ago. 
CORALLOID ROOT

Specialized cycad roots where useful bacteria live.

\section{ENDOPHYTE}

Any organism that lives inside a plant.

\section{SYMBIOSIS}

Any close and long relationship between two or more different organisms.

\section{RHIZOSPHERE}

The soil that is in direct contact with the roots of a plant.
As great as dinosaurs were, most of them went extinct while others eventually evolved into birds. However, cycads were able to survive until the present day, and still look almost exactly like their ancestors that lived alongside dinosaurs (Figure 1)! If that is not cool enough, cycads can live in extreme environmental conditions with very low nutrients where other plants cannot survive, including sand dunes, slopes, cliffs, and even on rocks [1].

How do cycads manage such amazing feats of survival? Cycads, like superheroes, have different abilities that allow them to resist difficult environments, but maybe their key superpower is inside their roots. Cycads can form unique root structures called coralloid roots, which look like tiny marine corals branching off the main root. Coralloid roots get nutrients for the plant, mainly nitrogen. Nitrogen $\left(\mathrm{N}_{2}\right)$ is an abundant gas in the atmosphere. $\mathrm{N}_{2}$ can be taken up by certain organisms and converted into ammonium $\left(\mathrm{NH}_{3}\right)$, which is a nutrient that cycads can use to live and grow. This process is called nitrogen fixation. Nitrogen fixation is one function performed by organisms called endophytes, which are microbes (bacteria, for example) that live inside of the coralloid roots. The endophytes are in an intimate interaction with the plant, called symbiosis [2].

To understand the cycad-endophyte symbiosis, we should think about our own bodies. We have all heard the saying, "You are what you eat" and you also may have heard that we should include certain bacteria, called probiotics, in our diets. It is true that the diet is an important way to get good bacteria to colonize (live in) some of our tissues and organs, such as the gut (Figure 2). The beneficial bacteria living inside us help us digest our food, generate healthy chemicals, and even protect us against dangerous microbes called pathogens [3]. But what about cycads? Are there bacteria living inside them? If so, what are those bacteria doing and how do they do it? Scientists trying to answer such questions have looked inside the coralloid roots for more than 100 years. However, it was only recently that we uncovered the high diversity of bacteria and the interesting functions of those bacteria inside the coralloid root, including the bacteria that perform nitrogen fixation.

First of all, where do these bacteria even come from? Well, we think that some of these microbes may be inherited from the plant's mother through the seed, similar to the way human babies obtain bacteria from their mothers by breastfeeding. But most of the bacteria inside the coralloid roots seem to come from the soil closest to the roots, called the rhizosphere. Cycads produce substances that attract the bacteria to the rhizosphere. Those bacteria then attach to the cycads surface and enter the internal tissues of the coralloid roots, through the numerous tiny holes in the walls of the plant's cells.

We know little about which soil-living bacteria can enter the cycads' roots, or even how many of them can actually stay in there. How 
Figure 1

Many living creatures have appeared and disappeared from the planet, while cycads kept on living. Their outside appearance is the same, but we think their roots have changed and are the secret for their survival.

Figure 2

Cycads, just like our bodies, have their own tiny bacterial helpers.

\section{CYANOBACTERIA}

Microorganisms with the ability of doing photosynthesis (just like plants!) and fixing nitrogen into useful compounds.
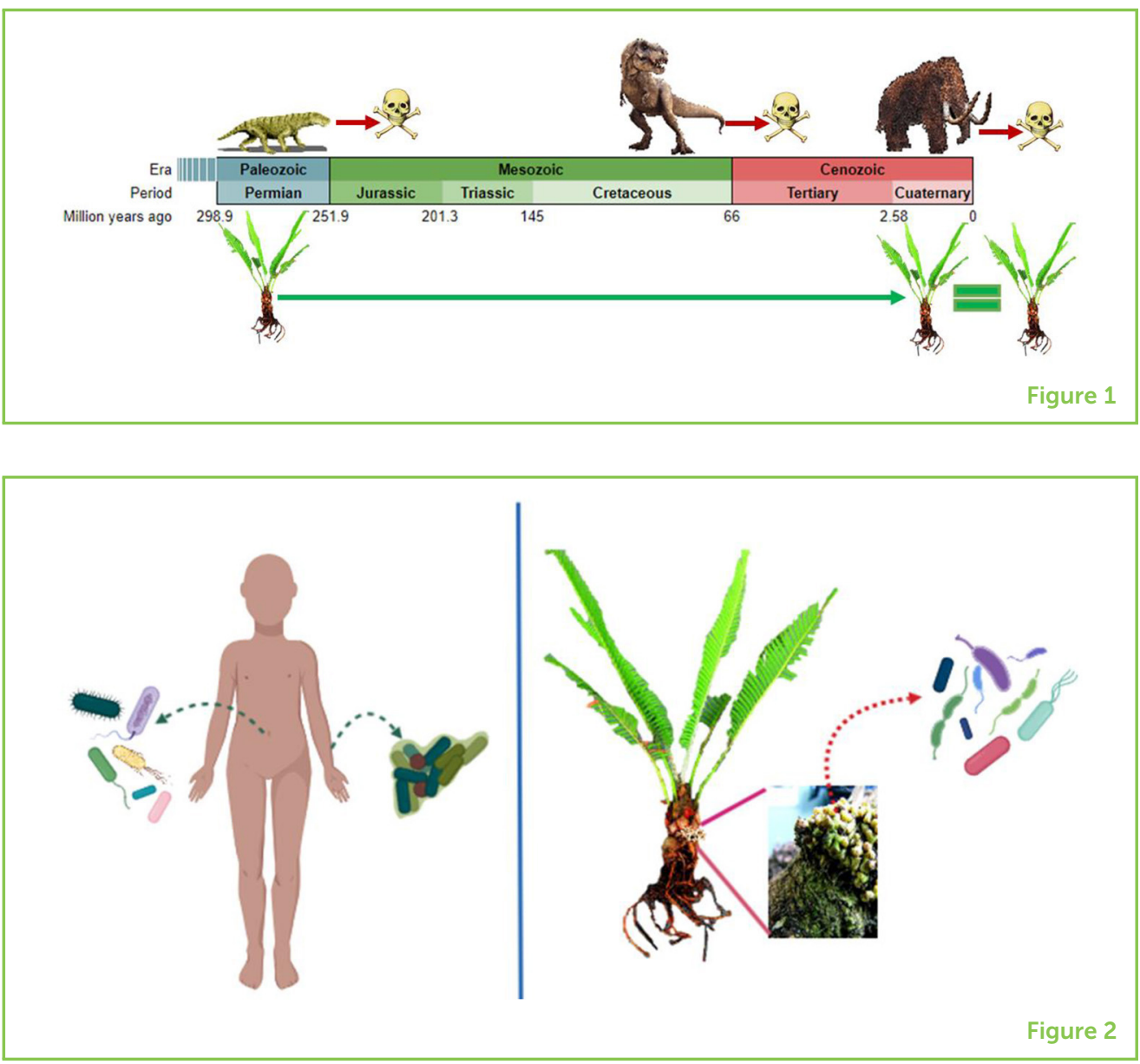

many types of bacteria are there inside the roots? Can all types of bacteria enter, or is this a special bacterial "VIP club"? What effect do these bacteria have on cycads? These key questions have not been answered yet, because most of the earlier studies performed on coralloid roots were focused on a very specific type of bacteria called cyanobacteria. Cyanobacteria are experts in nitrogen fixation, making them very important. But we thought that maybe, as in the human gut, there might be multiple types of bacteria, not just cyanobacteria. When we tested this idea, we found that there are many other microbes in the coralloid root, and that the roots might be a kind of "VIP club," in which only certain endophytes are included.

\section{A CLOSER LOOK INTO THE ROOTS OF THE CYCAD}

Our hypothesis was that the coralloid roots, and all the different microbes that are inside them, have an important role in the ability of cycads to thrive in difficult environments. To test this idea, we collected coralloid roots and soil samples from the Dioon genus of cycads, both from a botanical garden and from natural areas. A genus is a group comprised of many closely related species. The Dioon cycads are mostly found in Mexico and they are endangered, which makes them very hard to find, so we had to be very careful not to damage them. 
Figure 3

Different amounts and types of bacteria were found in all three compartments: coralloid roots rhizosphere and bulk soil of all plants studied. The types of bacteria are listed along the bottom, and the number shown next to each sample type shows whether a large or small number of that type was found in that sample. This figure combines the results of plants from both natural populations and botanical gardens. You can see that only some bacteria prosper in the roots, while others barely manage to grow.



Most of the cycads were growing in hard-to-reach places, so we had to have the correct instruments, a lot of determination, and a little bit of luck.

We collected coralloid root samples and stored them in liquid nitrogen (an extremely cold substance with a temperature around $-200^{\circ} \mathrm{C}$ ) to preserve the DNA. We also collected the rhizosphere and other soil from the area around the cycads. We separated the coralloid root samples by origin (natural location or botanical garden) and looked at the number of different species of bacteria in each of the soil and root samples.

\section{THE MANY, MANY FRIENDS OF THE CYCAD}

We found that there were 246 genera (plural of genus) of bacteria in the root and soil samples, but most of the bacteria in the samples fell into 10 genera (Figure 3). This told us that only a few groups of bacteria have really important roles. Curiously, we found a higher abundance of cyanobacteria species in natural samples than in botanical garden samples. Why did we find these differences? Perhaps because the soil from the natural locations has fewer nutrients than the soil in pots in the botanical garden. This might mean that cyanobacteria help cycads obtain nutrients from the soil, and are less necessary in botanical gardens than in nature. The coralloid-root "VIP club" includes other nitrogen-fixing bacteria in addition to cyanobacteria, such as Rhizobium, Bacillus, and Streptomyces, which are also known to live in the coralloid roots of other cycads besides Dioon.

Why do we call the coralloid root microbiome a VIP club? Because only a small fraction of the microorganisms living outside the cycad are able to get inside of the coralloid root. As a result, the numbers 
and types of bacteria inside the coralloid root are different than in the bulk soil and rhizosphere, as seen in Figure 3. Does the plant choose which bacteria are members of the VIP club? Or can only some types of bacteria survive inside the roots? Do these VIP bacteria have specific abilities that allow them be members of this club? Scientists are still answering these questions. What do you think?

Since the Dioon cycads that we studied are closely related to each other, we thought that they all might let the same types of bacteria into their coralloid roots. But we found differences in the types of bacteria in the roots of plants growing in natural sites vs. a botanical garden. We think this is due to the soil these cycads are growing in, as well as the small differences between the related plants. Think about humans again: it is known that human genes and diet shape the types of bacteria that are present in our guts. It could be the same with Dioon cycads-they could be sending different signals that attract different kinds of microorganisms to their roots. The exact mechanism for selecting the coralloid endophytes is still unknown, and the factors involved in choosing who is in each plant's VIP club remain to be discovered.

\section{HOW MIGHT CYANOBACTERIA HELP CYCADS SURVIVE?}

Are the bacteria living in the coralloid roots the key to the amazing survival of the cycads? To study this, scientists investigated whether cyanobacteria are able to produce special compounds that might help cycads survive. The scientists looked for sections of bacterial DNA that code for proteins called metabolites, which are substances that can help organisms survive under difficult environmental conditions. We call these parts of the DNA biosynthetic gene clusters, of BGCs for short [4].

BIOSYNTHETIC GENE CLUSTER (BGC)

Sections of DNA that produce specific substances.
Scientists searched for 77 known BGCs in the DNA of closely related cyanobacteria species. Of these BGCs, four were shared in all the types of cyanobacteria that we found inside the coralloid roots. These BGCs produced some toxins that can stop other bacteria from growing, possibly protecting the plant from harm. There are also metabolites and molecules that bacteria use to communicate with other endosymbionts and to provide nutrients for the plant, such as metallic-ion-carrier molecules called siderophores. These molecules help in the absorption of certain ions which otherwise would be inaccessible for the plant. These ions can mediate the metabolic response of several bacterial members of the community; thus changing the signals that the microorganisms receive from the environment. 


\section{SO, WHAT IS NEXT?}

The data gathered in this study gives us a pretty good picture of the bacterial community within the coralloid roots of the cycads. We now think it is possible that cycads have survived since the age of the dinosaurs without having to change on the outside because the cycads endophytes are the ones changing and providing new metabolites and abilities to deal with difficult conditions in the environment. However, there is still a lot we do not know about these plants and their endosymbionts, and scientists are still studying their interactions.

Before we wrap up, we will mention another intriguing observation made during our study. When looking inside the coralloid roots, we saw another type of organism that has barely been studied at all: fungi! So far, all we know about the fungi in the coralloid roots is that different types of fungi live in a single species of cycad. How the fungi affect other organisms and how they interact with the cycad and the bacterial endosymbionts is currently unknown. We think fungi may be acting as a network to move metabolites to the plant, or maybe as protectors of the plant or the bacteria. But the fungi could also be competing for space inside the roots, forcing the bacteria to work together. As you can see, there are still a lot of things to study about these ancient plants and their coralloid roots. What we learn about these plants might help us understand how symbiotic relationships between organisms originally formed in plants, and how these relationships are regulated. Since all known organisms depend upon their relationships with one another, this information could tell us a lot about how living things have survived and developed over the course of evolutionary history, not as isolated beings, but as parts of communities. Only time will tell what future discoveries will show about the beings we share the world with!

\section{ORIGINAL SOURCE ARTICLE}

Suarez-Moo, P. J., Vovides, A., Griffith, M. P., Barona-Gómez, F., and Cibrian-Jaramillo, A. 2019. Unlocking a high bacterial diversity in the coralloid root microbiome from the cycad genus Dioon. PLOS ONE 14:e0211271. doi: 10.1371/journal.pone.0211271

\section{REFERENCES}

1. Norstog, K. J., and Nicholls, T. J. 1997. The Biology of the Cycads. New York, NY: Cornell University Press.

2. Kneip, C., Lockhart, P., Voß, C., and Maier, U. G. 2007. Nitrogen fixation in eukaryotes-new models for symbiosis. BMC Evol. Biol. 7:55. doi: 10.1186/1471-2148-7-55

3. Christian, N., Whitaker, B. K., and Clay, K. 2015. Microbiomes: unifying animal and plant systems through the lens of community ecology theory. Front. Microbiol. 6:869. doi: 10.3389/fmicb.2015.00869 
4. Gutierrez-Garcia, K., Bustos-Díaz, E. D., Corona-Gomez, J. A., Ramos-Aboites, H. E., Selem-Mojica, N., Cruz-Morales, P., et al. 2019. Cycad coralloid roots contain bacterial communities including Cyanobacteria and Caulobacter spp. that encode niche-specific biosynthetic gene clusters. Genome Biol. Evol. 11:319-34. doi: 10.1093/gbe/evy266

SUBMITTED: 01 May 2019; ACCEPTED: 16 December 2019; PUBLISHED ONLINE: 23 January 2020.

EDITED BY: Francisco Barona-Gomez, National Laboratory of Genomics for Biodiversity, Center for Research and Advanced Studies of the National Polytechnic Institute, Mexico

CITATION: López Restrepo F, Garfias Gallegos D and Suarez Moo PdJ (2020) Cycads: Ancient Plants With Bacteria Living in Their Roots. Front. Young Minds 7:156. doi: 10.3389/frym.2019.00156

CONFLICT OF INTEREST: The authors declare that the research was conducted in the absence of any commercial or financial relationships that could be construed as a potential conflict of interest.

COPYRIGHT @ 2020 López Restrepo, Garfias Gallegos and Suarez Moo. This is an open-access article distributed under the terms of the Creative Commons Attribution License (CC BY). The use, distribution or reproduction in other forums is permitted, provided the original author(s) and the copyright owner(s) are credited and that the original publication in this journal is cited, in accordance with accepted academic practice. No use, distribution or reproduction is permitted which does not comply with these terms.

\section{YOUNG REVIEWERS}

\section{AURA, AGE: 14}

My name is Aura. I am 14 years old. I live in Guanajuato Mexico and I love dancing. I think all the sciences are very interesting.

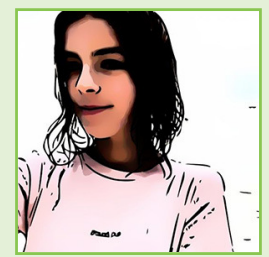

\section{MANU, AGE: 14}

My name is Manuela but everyone calls me Manu. I am 14 years old and I am in my second year of secondary school. I love horse riding and arts. When I grow up I would like to be a marine biologist or to study gastronomy.

\section{AUTHORS}

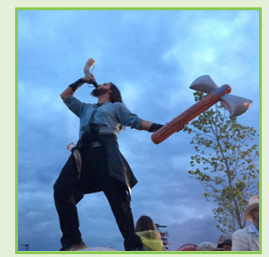

\section{FERNANDO LÓPEZ RESTREPO}

I am a graduate student with a passion for the world around us and all of its inhabitants. I have a background in the study of circadian rhythms, environmental stress, and organism interactions. I first became interested in science and biology 
by reading about the animals we share the world with, and my thirst for knowledge never stopped since. I am also passionate about history, music, and creature design. *fernando.lopez.racinvestav.mx

\section{DIEGO GARFIAS GALLEGOS}

An art enthusiast since the time when the Bach and Chopin melodies drive me to see that there are questions worth to be asked and answers that are better to attack by different perspectives. Obsessed with fantasy and unseen worlds like the ones Tolkien or Bradbury depicted and what in the end drive me to search answers in science, were there are entire worlds waiting to be discovered.

\section{PABLO DE JESÚS SUAREZ MOO}

I am currently an associate professor at the Institute of Ecology (INECOL), Mexico, where I study the role of the microorganisms (microbiome) in the welfare (fitness) of plants and animals. When I started studying biology, my research interest was the biology of sharks (sharks are so awesome), but now I am interested in the microscopic world (mainly fungi and bacteria) and your association (symbiosis) with the plants and animals. With the new technologies, we discover news beneficial properties of the microorganisms to their hosts (is so cool!). 